\title{
How Does Information Communication Technology Affect Energy Use?
}

\author{
Stefano B. Longo \\ Department of Sociology and Anthropology, \\ North Carolina State University, Raleigh, United States \\ Richard York \\ Department of Sociology and Environmental Studies Program, \\ University of Oregon, Eugene, United States
}

\section{Abstract}

In recent decades there has been considerable optimism that information communication technologies may lead to structural transformations of production, consumption, and transportation systems, helping to reduce energy consumption. Here we analyze the effects of information communication technologies on energy production and consumption as well as on the number of cars used in nations, analyzing data for 1990-2012. We find that the prevalence of landline phones is positively associated with higher levels of energy and electricity production and consumption, that the extent of Internet use is positively associated with the number of cars on the road, and the ubiquity of cell phones is not associated with the number of cars or with electricity or total energy production and consumption. These findings suggest that information communication technologies have not typically contributed to environmental reform and, in fact, may have exacerbated some environmental problems.

\section{Introduction}

Technological innovation has long been regarded as a mechanism with the potential to increase the efficiency of production systems. With the rapid expansion of information communication technologies (often referred to by the acronym ICTs) in recent decades, such as Internet access and cell phones, there has been considerable enthusiasm that these technologies will offer important contributions toward addressing many environmental problems and concerns faced by modern societies. In this paper, we assess the relationship between information communication technologies and the energy use of nations. We develop national-level panel models to assess whether these technologies have produced positive environmental outcomes. 
Research on environmental problems has become an area of growing interest in the natural and social sciences. Commonly, the development, application, and diffusion of technologies are regarded as central components for advancing social and ecological sustainability. That is, technological change is considered to be a central tool for postponing, alleviating, or solving ecological problems. Within science and policy circles, this postulation is sometimes referred to as "technological optimism" (Foster, Clark, \& York, 2010). Although the social sciences have developed theoretical approaches that are more nuanced, the role of technology is often at the forefront for understanding environmental problems and proposed social reforms for addressing them (Fisher \& Freudenburg, 2001; York \& Clark, 2010).

In the social sciences, some economists have advanced theories that suggest technological innovations together with open markets will lead to continually advancing systems of production and consumption that can overcome any natural limits (Simon, 1981). In the area of environmental concerns, these economic theories submit that market forces will provide the most efficient outcomes when technologies are developed and applied in order to meet market demands, which include the demand for a cleaner and safer environment. Free markets are purported to prompt behaviors in social agents (individuals and firms) that improve the efficiency of production and consumption. Technologies are applied in this context with an eye toward advancing self-interest and profits. In doing so, new technologies are expected to advance the substitution of lower cost inputs and production processes for those that are more costly and less efficient, which are expected to benefit both producers and consumers. New technologies can increase environmental benefits by proportionately reducing material and energy throughputs due to more cost-effective production that reduces the natural resources necessary per unit of output. Also, by shifting from usage of resources that are overexploited and scarce (and thus more expensive), to more abundant or human-produced alternatives, environmentally beneficial improvements are anticipated.

Sociologists have also developed theoretical approaches that consider the effects of technological change on environmental outcomes. Here we consider the applicability of one of the leading theoretical perspectives in environmental sociology: ecological modernization theory (Mol \& Spaargaren, 2000). The foundations of this approach lie in theorizing on the process of modernity and its relationship to the biophysical environment. The approach contextualizes the environmental conditions in the modern era. According to ecological modernization theorists, modernity has been associated with not only harmful, but also beneficial developments for humans and the environment. Thus, supporters of the theory have often been critical of research that 
ignores the potential for the institutional processes of modernity to respond to environmental concerns and ameliorate human impacts on the environment (Mol, 2002).

Ecological modernization theory has advanced an approach that considers the various institutional forces that are at work in modern society and their relationships to environmental change. Among other important contributions, researchers have defined a variety of social processes that can direct societies toward environmental reforms. These processes include the increasing importance of market dynamics and economic agents (both producers and consumers); the changing role of the nation-state; modifications in the position, role, and ideology of social movements; and changing discursive practices and emerging new ideologies. In the context of these modernizing institutional processes, technological change has increasing potential to address existing and emerging environmental problems (Fisher \& Freudenburg, 2001). Ecological modernization theory develops a multi-level explanation of environmental outcomes in which economic practices in the realms of production and consumption, political change, and cultural processes interact to further the capacity for an ecologically sustainable modernity.

The potential for technological change, such as those in the information communication sector, to advance social and ecological sustainability in the context of a growing capitalist economy is a principal tenet of economic marketbased theories and ecological modernization theory. Technological change obviously plays an important role in producing what ecological modernization theorists have called "ecological rationalities" (Mol \& Spaargaren, 2000), whereby there is the potential for dematerialization of production and consumption, or a decoupling of the economy and the environment, and natural resources and waste emissions are reduced even as the economy continues to grow (Mol, 2002; Jorgenson \& Clark, 2012). With information communication technologies, dematerialization can come about, for example, as new communication technologies optimize production processes, eliminate redundancies and waste, and reduce travel and commuting. Further, information production and consumption are often considered "distinct from material and energy," and can act as substitutes for physical resources (Berkhout \& Hertin, 2004, p. 905).

However, other theories in environmental sociology are skeptical of the claims made by ecological modernization theorists. Critical environmental sociological approaches offer competing theoretical explanations for the relationship between technological development and environmental problems in the modern era. These theoretical traditions, including human ecology, treadmill of production, and metabolic rift, are less optimistic about how technological change can lead to meaningful environmental benefits in capitalist economies (Foster, Clark, \& York, 2010; Schnaiberg, 1980; York, Rosa, \& Dietz, 2003a, 2010). 
Making use of the logic of the I=PAT (Impacts = Population $\mathrm{x}$ Affluence $\mathrm{x}$ Technology) model and its stochastic transformation, STIRPAT model, the human ecology tradition theorizes technology's effect on the environment in a multiplicative relationship with other variables, and thus it is a sort of wildcard variable, one that can either decrease or increase environmental impacts (York, Rosa, \& Dietz, 2003a, 2003b). Treadmill of production theory emphasizes the growth dynamic in modern economies. This theory suggests that a coalition of social interests, including private corporations, labor, and the state, combine to continually advance economic growth, which drives increasing environmental inputs (e.g., pollution) and withdrawals (e.g., clear cut forests). Further, these theorists suggest that research and development in technology are biased toward those that increase productivity (and consequently displace workers), which accelerates the treadmill of production, since growth in production is needed to avoid an unemployment crisis (Schnaiberg \& Gould, 1994). Other critical environmental sociological perspectives, including metabolic rift, suggest that technological development under capitalist social relations primarily serves capital accumulation (Foster, 1994; Foster, Clark, \& York, 2010). Therefore, ecological benefits are often sacrificed for profits. Further, capitalist development is generally inclined toward a paradox of increasing technological efficiency of production (due to the motivation to decrease costs), but also increasing aggregate resource use driven by the growth imperative of capital (Foster, Clark, \& York, 2010; Longo, Clausen \& Clark, 2015; York, 2006). ${ }^{1}$

In this paper, we examine the competing claims of ecological modernization theory and critical environmental sociology in relation to structural changes in economic processes associated with information communication technologies and ecological outcomes. In particular, we look at the relationship between Internet usage, phone lines, and cell phone use and levels of energy production and consumption, including an analysis of electricity and of car ownership. Drawing on these theoretical approaches, we test the hypothesis that information communication technology, particularly cell phones and Internet use, serve to reduce the production and consumption of energy in nations.

\footnotetext{
1 Scholars have referred to this as the "Jevons Paradox," named after the 19th-century economist William Stanley Jevons, who observed that increasing efficiency of coal production led to increases in coal consumption, not decreases, due to the growth in coal-fueled technologies outpacing efficiency. Modern economists and others sometimes refer to this dynamic as the "rebound effect," which we mention later in the paper (see Clark and Foster, 2001; Plepys, 2002).
} 


\section{Information communication technology and the environment}

Over the last several decades, environmental researchers have been increasingly interested in examining the potential for new technologies to alleviate environmental concerns related to energy production and consumption. Modern energy systems rely primarily on burning fossil fuels. These technologies have made a central contribution to industrial development. Fossil fuel energy production systems have been fundamental in furthering economic development throughout the world. However, it is widely recognized that fossil fuel combustion is also at the center of numerous environmental problems, including global climate change.

As a result of the severe social and ecological consequences of modern energy production systems, there are growing efforts in the scientific research community and policy circles to find solutions through technological change. As such, increasing the efficiency of energy use has been a leading policy approach in these matters. Methods of reducing the intensity of energy consumption in relation to economic output are a way to continue socioeconomic development, while reducing the associated environmental costs (Ghosh, 2002; Mathiesen, Lund, \& Karlsson, 2009). In the social science research on economic development, economic growth is a central factor for maintaining and expanding the wellbeing of populations both in the wealthy nations of the global North, and the less wealthy nations of the global South. Therefore, understanding the potential for technologies to reduce the energy intensity of production and consumption within a nation is viewed as a key area for tackling modern environmental concerns such as climate change (Goldemberg, 1998).

The growth and application of information communication technologies over the last several decades has been significant, and are often seen as important developments in relation to addressing climate change. New information communication technologies such as the Internet and cell phones are considered essential to enhancing the efficiency of existing systems of energy production, as well as to developing new energy technologies that can decrease energy use (Walker, 1986). The advances in information communication technologies are expected to produce economic expansion that is decreasingly tied to expansion of energy consumption (Romm, 2002). For example, production and consumption of information can increase, but require less energy use than might be applied to material production and consumption. Researchers argue that powerful new information technologies in advanced capitalist nations will be associated with new production practices, "raising the efficiency with which energy is used in many parts of the economy" (Walker, 1985, p. 458). 
In an analysis developed for the Center for Energy and Climate Studies, Romm et al. (1999) presented an enthusiastic analysis of the increasing benefits offered by the information technology sector. This report and a follow-up article based on it (Romm, 2002) contend that growth in the information technology sector will lead to energy efficiency and will have important implications for developing solutions to climate change for two reasons. First, the information technology sector is an area of the economy that is less energy-intensive than other areas of the productive economy, such as manufacturing. Second, new information technologies will make other areas of the economy more efficient by producing new innovations that will increase energy saving (and greenhouse gas curbing) practices in production. These latter changes are particularly important as they point to the structural changes in the economy that will alter the energy characteristics of production. The spread of Internet access, new hardware, and software systems will promote economy-wide structural change, resulting in the dematerialization of production. As the economy shifts toward a greater share of production in more energy efficient information technology sectors, it will (at the same time) make other economic sectors more efficient. Thus, technological transformations will make "e-materialization" possible (Romm, 1999). That is, dematerialization will occur through developments in information communication technologies.

Researchers submit that information communication technologies can structurally affect the energy intensity of a society by altering production and consumption systems (Romm, 1999; Laitner \& Ehrhardt-Martinez, 2008). This suggests that the growth in information communication technologies fundamentally modify the methods and organization of production and consumption. For example, the expansion of Internet and cell phone technologies can reduce automobile usage and dependence as it promotes online shopping, decreases trips for errands and entertainment (for example, banks, libraries, or movie theaters), and promotes telecommuting for workers and online courses for students. As automobile use is a major contributor to greenhouse gas accumulation in the atmosphere, these deviations from previous practices can reform the structure of the economy in a more environmentally sustainable manner.

Laitner (2002) notes that, in the United States, significant gains in energy efficiency have been made during the late 20th and early 21 st centuries, and considers whether information and communication technologies have "significantly reduced the nation's energy intensity" (Laitner, 2002, p. 15). The analysis concluded that the "initial evidence with respect to information technologies appears to support a trend toward decreasing energy intensity" (Laitner, 2002, p. 20). Similarly, Laitner and Ehrhardt-Martinez (2008) assert that information and communication technologies have played an important role in significant energy savings throughout the U.S. economy. They argue that these 
technologies have been critical to increasing energy efficiency and reducing waste. The authors point out that there has been growing attention paid to the energy-consuming aspects of information and communication technologies (for example, server farms), calling this "the ICT energy paradox." They suggest that the focus should be on the energy-saving capacity that will result from the widespread application of the new technologies in production processes (Laitner \& Ehrhardt-Martinez, 2008, p. 48).

In fact, numerous researchers have considered aspects of this energy paradox and other paradoxes associated with information communication technology and the environment (Berkhout \& Hertin, 2004; Fuchs, 2008; Hilty et al., 2006; Moyer \& Hughes, 2012; Plepys, 2002). The indirect effects of information communication technological development can result in increased efficiency and dematerialization, such as improving the productivity of labor, capital, and natural resources, as well as structural changes to an economy, including consumer behaviors (Berkhout \& Hertin, 2004; Hilty et al., 2006). Even while these processes are driven by the desire to reduce costs, it is suggested that they tend to have positive environmental benefits as they can be, for example, less polluting (Berkhout \& Hertin, 2004). However, the information communication technology can also have direct effects, or first-order effects, from the manufacture and use of the technology, which may be environmentally damaging (Hilty et al., 2006). Producing technologies such as semi-conductors and liquid crystal displays, for example, can result in increased energy and resource use and toxic emissions (Berkhout \& Hertin, 2004). Thus, the dematerializing effects and re-materializing influences must be assessed in tandem.

Moyer and Hughes (2012) maintain that advances in information communication technologies can concurrently improve economic productivity and reduce energy intensity. However, they argue that in order to substantially reduce carbon emissions and address concerns related to climate change, innovations in these technologies must be coupled with a global price on carbon. Accordingly, new information communication technologies must be accompanied by new environmental policies that will together provide potential environmental benefits.

Others have examined the ways in which information communication technologies can increase efficiency and economic growth, but paradoxically result in rebound effects in the energy sector (Plepys, 2002; Hilty et al., 2006). That is, the reduction of energy costs can spur increases in production and consumption that impede the potential improvements in environmental outcomes. Plepys (2002) suggests that there may be too much optimism about the positive role of information communication technologies regarding environmental impacts. 
This research contends that direct and especially higher-order impacts on the economy and the environment should be better understood, illustrating the complexity of the relationship between technology and environmental impacts.

Fuchs (2008) considers the potential for new information communication technologies to foster environmental sustainability and contends that economic processes associated with advancements in technology have generally prioritized profit maximization. As a result, they have not always had the positive effects that many have hoped for, particularly in the global South. The benefits of information and communication technologies on the environment are shaped by economic imperatives, and thus environmental sustainability is not an inevitable outcome (Fuchs 2008).

Similar to our present study, Sandorsky (2012) models the effects of information communication technologies in 19 "emerging economies." The study employs three per capita measures of information communication technologies: the number of Internet connections; the number of mobile phone subscriptions; and the number of personal computers. The study finds that use of information communication technology has a positive and significant relationship with energy consumption (Sadorsky, 2012). Further, in an assessment of worldwide electricity consumption of information communication technologies from 2007 to 2012, researchers found that "combined electricity consumption of communication networks, personal computers and data centers is growing at a rate of nearly 7\% per year (i.e., doubling every 10 years)" (Heddeghem et al., 2014 , p. 75). Thus, while there have been continuing efforts toward increasing energy efficiency, total energy consumption in the sector increased over this period of time (Heddeghem et al., 2014).

The body of research we have reviewed suggests that information communication technologies may lead to reductions in energy use. However, this literature also points to the possibility that these technologies may be ineffective at bringing about environmental benefits due to structural characteristics of the global economy that prioritize profit maximization and potentially subvert the benefits that may come from technological developments. Here we contribute to this scholarly discussion by empirically assessing the degree to which information communication technologies have been associated with levels of overall energy production and consumption, electricity production and consumption, and the number of cars in nations around the world. 


\section{Data and methods}

We use national-level panel models to assess the relationship between three different types of information communication technologies (phone lines, Internet usage, and cell phones) and five different dependent variables that measure different aspects of energy use or that are closely connected with energy use (energy use per capita, energy production per capita, electricity production per capita, electricity consumption per capita, and the prevalence of passenger cars). ${ }^{2}$ To the extent data allowed, we analyzed data from 1990 to 2012, the most recent year for which data are available for most nations. We include all nations and time points in the specified time range for which there are data on all variables, or for which we could reasonably interpolate data, in the models.

The sample of nations varies somewhat across models based on data availability, ranging from 121 to 135, and not all nations have data for all years. In all models the sample of nations includes those that contain the vast majority of the world's population, economic activity, and energy production and consumption.

We estimate fixed effects panel models using the Prais-Winsten correction for first order autocorrelation, including dummy variables for each year to control for period effects. We also include a suite of independent variables commonly employed in research on energy use as controls. All of our data come from the World Bank's (2014) World Development Indicators.

\section{Dependent variables}

For each of the five models we estimated the effects of the independent variables on unique dependent variables. In the first two models we employ measures of energy production and consumption as dependent variables. The first model tests for the effect of the independent variables on energy use per capita. This variable represents forms of primary energy consumption-including fossil fuels, combustible renewables and waste, and primary electricity (e.g., nuclear and hydropower) - before conversion to end uses and is equal to indigenous production plus imports minus exports. The second model employs energy production per capita as the dependent variable. This variable reflects indigenous production of the same forms of energy accounted for in energy use. Both of the above variables are measured in kilograms of oil equivalent.

In the third and fourth models, we use measures of electricity consumption and production per capita. The electricity variables are measured in kilowatt-hours. We utilize a measure of automobile dependence in the final model: passenger

2 Unlike Sandorsky's (2012) study, which examined only 19 emerging economies, we do not include personal computers since the data are not available for most of the nations/times we examine here. 
cars per 1,000 people. This measure includes road motor vehicles, excluding two-wheelers, designed for carrying nine or fewer passengers. Data on this final variable are only available for 2000 to 2011 . The five dependent variables we examine are fairly closely connected (see Table 1 for a correlation matrix for the year 2000), but each measures a distinct aspect of the energy production and consumption system in nations.

Table 1. Pairwise correlation (Pearson's r) matrix of dependent variables for the year 2000

\begin{tabular}{|l|c|c|c|c|c|}
\hline & $\mathbf{1 .}$ & $\mathbf{2 .}$ & $\mathbf{3 .}$ & $\mathbf{4 .}$ & $\mathbf{5 .}$ \\
\hline 1. Energy use p.c. & 1.000 & & & & \\
\hline 2. Energy production p.c. & 0.743 & 1.000 & & & \\
\hline 3. Elec. Consumption p.c. & 0.835 & 0.508 & 1.000 & & \\
\hline 4. Elec. Production p.c. & 0.776 & 0.538 & 0.943 & 1.000 & \\
\hline 5. Cars per 1000 people & 0.660 & 0.224 & 0.752 & 0.672 & 1.000 \\
\hline
\end{tabular}

\section{Independent variables}

The independent variables included in all models consist of the three variables of interest along with a variety of control variables. The first variable used as a measure of information communication technology is phone lines per 100 people. Telephone lines report the number of connections to the telephone system. Next, we use a measure of cell phone usage per 100 people. Cell phones report the number of subscriptions to mobile phone services. The third variable of interest associated with information communication technology is Internet users per 100 people. Internet users are people who have used the Internet in the last 12 months. Where missing values were reported at the beginning of the time series, they were imputed to be 0 . Missing values in the series after the first measured value were interpolated assuming a linear trend. The imputation of missing values increases the observations in each model by about $10 \%$, except for the cars model, where it adds only 14 observations. Note that the substantive findings we report below are the same if the imputed values are excluded. Internet users per 100 people has a high correlation (Pearson's $r=.86$ ) with Internet subscribers per 100 people, so the two are similar measures. Internet users variable is used instead of subscribers because it has more than $50 \%$ better data coverage. These three key independent variables (phone lines, cell phones, and Internet users) are fairly highly correlated with one another, with pairwise correlations among them ranging from .82 to .86 for the year 2000, indicating 
they are closely connected; although clearly based on face validity they each measure a different aspect of the information communication technology system of nations. ${ }^{3}$

The control variables included in the models have been established to be the primary forces influencing energy use variously measured. As a measure of national affluence, we include GDP per capita in 1,000s of constant year 2005 U.S. dollars and the quadratic of GDP per capita. The quadratic of GDP is used to allow for a non-linear relationship between GDP per capita and the dependent variables. This is a common method used to test for the presence of Environment Kuznets Curve (EKC). The EKC is an inverted " $U$ " shaped distribution that has been used to assess potential non-linear effects of economic growth on various environmental outcomes (Dinda, 2004). We also include the percentage of GDP that comes from the industrial sector and the percentage of GDP that comes from the service sector to control for the structure of the economy.

We also include measures of global economic activities that can affect energy production and consumption in our models: the value of imports as a percentage of GDP, the value of exports as a percentage of GDP, and foreign direct investment inflows as a percentage of GDP. Demographic variables included in the models are the percentage of the population living in urban areas, and the age dependency ratio. Finally, we include a measure on military expenditures as a percentage of GDP.

\section{Results}

The results of our analyses are presented in Table 2. Since our focus is on information communication technologies, we will only very briefly comment on the effects of the other variables. GDP per capita is clearly significant in each model, as is its quadratic. While the negative quadratic term suggests that the effect of economic growth on the dependent variables attenuates as GDP per capita rises, in all models the projected turning point on an EKC is over $\$ 60,000$, a value beyond the reach of most nations. In most models, most of the other control variables do not have significant effects. The exceptions are: energy use is affected by urbanization and the age dependency ratio; energy production is

\footnotetext{
3 These correlations are not sufficiently high to raise concerns about multicollinearity. It is difficult to assess the extent to which multicollinearity may affect results in fixed effects panel models since statistics like the VIF cannot be calculated in a straightforward way due to how variance is parsed across units and over time. However, indications are that multicollinearity is not a serious problem in our models. For example, if all of the observations (nation-years) are simply pooled and analyzed using a standard OLS regression model instead of using a panel approach, thereby allowing for the estimation of VIFs, no variable has a VIF in excess of 10, except for GDP per capita and its quadratic, which is to be expected.
} 
affected by industrialization, imports, and exports; electricity consumption is affected by FDI inflows and the age dependency ratio; and electricity production is affected by the age dependency ratio.

Table 2. Fixed effects panel regression analyses of per capita energy use and production, per capita electricity consumption and production, and passenger car ownership per 1,000 people for most nations of the world, 1990-2012

\begin{tabular}{|c|c|c|c|c|c|}
\hline $\begin{array}{l}\text { Independent } \\
\text { Variable (I.V.) }\end{array}$ & $\begin{array}{l}\text { Energy use } \\
\text { per capita } \\
\text { Coef. (S.E.) }\end{array}$ & $\begin{array}{c}\text { Energy prod. } \\
\text { p.c. } \\
\text { Coef. (S.E.) }\end{array}$ & $\begin{array}{l}\text { Electricity } \\
\text { cons p.c. } \\
\text { Coef. (S.E.) }\end{array}$ & $\begin{array}{l}\text { Electricity } \\
\text { prod. p.c. } \\
\text { Coef. (S.E.) }\end{array}$ & $\begin{array}{c}\text { Cars per } \\
1,000 \\
\text { Coef. (S.E.) }\end{array}$ \\
\hline $\begin{array}{l}\text { GDP pc } \\
(1,000 \$)\end{array}$ & $\begin{array}{c}171.565^{\star \star \star} \\
17.100) \\
\end{array}$ & $\begin{array}{c}748.530^{\star \star \star} \\
(50.093) \\
\end{array}$ & $\begin{array}{c}175.267^{\star \star \star} \\
(17.311)\end{array}$ & $\begin{array}{c}271.987^{\star \star \star} \\
(27.788) \\
\end{array}$ & $\begin{array}{c}9.061^{\star \star \star} \\
(1.757)\end{array}$ \\
\hline$(\mathrm{GDP} p \mathrm{pc})^{2}$ & $\begin{array}{c}-1.059^{\star \star \star} \\
(0.181)\end{array}$ & $\begin{array}{c}-4.601^{\star \star \star} \\
(0.522)\end{array}$ & $\begin{array}{l}-0.365^{\star} \\
(0.186)\end{array}$ & $\begin{array}{c}-1.905^{\star \star \star} \\
(0.311)\end{array}$ & $\begin{array}{c}-0.069^{\star \star \star} \\
(0.020)\end{array}$ \\
\hline $\begin{array}{l}\text { Urban pop. } \\
\text { (\%) }\end{array}$ & $\begin{array}{l}-21.704^{*} \\
(10.097)\end{array}$ & $\begin{array}{l}63.437 \\
(39.544)\end{array}$ & $\begin{array}{c}-2.284 \\
(10.005)\end{array}$ & $\begin{array}{c}13.551 \\
(12.407)\end{array}$ & $\begin{array}{c}0.540 \\
(0.660)\end{array}$ \\
\hline $\begin{array}{l}\text { Indust. } \\
\text { (\% GDP) }\end{array}$ & $\begin{array}{l}2.318 \\
(2.323)\end{array}$ & $\begin{array}{l}15.951^{\star} \\
(6.537)\end{array}$ & $\begin{array}{l}1.750 \\
(2.347)\end{array}$ & $\begin{array}{l}3.094 \\
(6.546)\end{array}$ & $\begin{array}{l}0.037 \\
(0.485)\end{array}$ \\
\hline $\begin{array}{l}\text { Service } \\
\text { (\% GDP) }\end{array}$ & $\begin{array}{l}2.472 \\
(2.183)\end{array}$ & $\begin{array}{l}5.160 \\
(6.167) \\
\end{array}$ & $\begin{array}{l}1.916 \\
(2.212) \\
\end{array}$ & $\begin{array}{l}-7.811 \\
(6.094) \\
\end{array}$ & $\begin{array}{c}0.369 \\
(0.409) \\
\end{array}$ \\
\hline $\begin{array}{l}\text { Imports } \\
\text { (\% GDP) }\end{array}$ & $\begin{array}{l}-1.244 \\
(0.951) \\
\end{array}$ & $\begin{array}{c}-15.726^{\star \star \star} \\
(2.688) \\
\end{array}$ & $\begin{array}{c}1.026 \\
(0.967) \\
\end{array}$ & $\begin{array}{l}-2.782 \\
(2.329) \\
\end{array}$ & $\begin{array}{l}-0.247 \\
(0.168) \\
\end{array}$ \\
\hline $\begin{array}{l}\text { Exports } \\
\text { (\% GDP) }\end{array}$ & $\begin{array}{c}1.222 \\
(1.115) \\
\end{array}$ & $\begin{array}{c}18.612^{\star \star \star} \\
(3.159)\end{array}$ & $\begin{array}{l}-0.371 \\
(1.135) \\
\end{array}$ & $\begin{array}{l}-0.260 \\
(2.655) \\
\end{array}$ & $\begin{array}{l}-0.157 \\
(0.210) \\
\end{array}$ \\
\hline $\begin{array}{l}\text { Military exp. } \\
\text { (\% GDP) }\end{array}$ & $\begin{array}{c}0.389 \\
(4.203) \\
\end{array}$ & $\begin{array}{c}-1.467 \\
(11.769) \\
\end{array}$ & $\begin{array}{l}-0.073 \\
(4.249) \\
\end{array}$ & $\begin{array}{c}3.242 \\
(10.697) \\
\end{array}$ & $\begin{array}{c}0.676 \\
(1.697) \\
\end{array}$ \\
\hline $\begin{array}{l}\text { FDI inflows } \\
\text { (\% GDP) }\end{array}$ & $\begin{array}{c}0.512 \\
(0.746)\end{array}$ & $\begin{array}{l}-1.784 \\
(2.094)\end{array}$ & $\begin{array}{c}2.877^{\star \star *} \\
(0.765)\end{array}$ & $\begin{array}{c}1.383 \\
(1.920)\end{array}$ & $\begin{array}{l}-0.116 \\
(0.092)\end{array}$ \\
\hline Age dep. ratio & $\begin{array}{c}-22.307^{\star \star \star} \\
(5.491) \\
\end{array}$ & $\begin{array}{c}29.580 \\
(19.159) \\
\end{array}$ & $\begin{array}{c}-16.509^{\star *} \\
(5.415) \\
\end{array}$ & $\begin{array}{c}-15.719^{\star} \\
(7.655) \\
\end{array}$ & $\begin{array}{c}0.266 \\
(0.620) \\
\end{array}$ \\
\hline $\begin{array}{l}\text { Phone lines } \\
\text { (per 100) }\end{array}$ & $\begin{array}{l}9.319^{\star \star} \\
(2.982)\end{array}$ & $\begin{array}{c}40.115^{\star \star \star} \\
(8.710) \\
\end{array}$ & $\begin{array}{c}13.374^{\star \star \star} \\
(2.968) \\
\end{array}$ & $\begin{array}{c}18.651^{\star * \star} \\
(4.580)\end{array}$ & $\begin{array}{c}0.462 \\
(0.343) \\
\end{array}$ \\
\hline $\begin{array}{l}\text { Cell phones } \\
\text { (per 100) }\end{array}$ & $\begin{array}{l}1.135 \\
(0.662) \\
\end{array}$ & $\begin{array}{l}-3.410 \\
(1.910) \\
\end{array}$ & $\begin{array}{c}1.177 \\
(0.662) \\
\end{array}$ & $\begin{array}{c}0.819 \\
(1.210) \\
\end{array}$ & $\begin{array}{c}0.159 \\
(0.085) \\
\end{array}$ \\
\hline Internet users & $\begin{array}{l}-2.327 \\
(1.414) \\
\end{array}$ & $\begin{array}{l}-0.629 \\
(4.153) \\
\end{array}$ & $\begin{array}{c}1.065 \\
(1.393) \\
\end{array}$ & $\begin{array}{c}1.691 \\
(2.242) \\
\end{array}$ & $\begin{array}{c}0.683^{\star \star \star} \\
(0.187) \\
\end{array}$ \\
\hline $\mathrm{R}^{2}(\mathrm{w} / \mathrm{b} / \mathrm{O})$ & $\begin{array}{c}0.154 / 0.194 / \\
0.040\end{array}$ & $\begin{array}{c}0.191 / 0.120 / \\
0.074\end{array}$ & $\begin{array}{c}0.286 / 0.433 / \\
0.114\end{array}$ & $\begin{array}{c}0.194 / 0.006 / \\
0.004\end{array}$ & $\begin{array}{c}0.205 / 0.096 / \\
0.002\end{array}$ \\
\hline $\mathrm{N} /$ countries & 2148/135 & $2111 / 124$ & $2077 / 124$ & $2111 / 124$ & $965 / 121$ \\
\hline
\end{tabular}

Notes:

- ${ }^{*} p<.05,{ }^{* \star} p<.01,{ }^{* *} p<.001$

- Models correct for AR(1) disturbances using the Prais-Winsten method. The model for car ownership uses data for only 2000 to 2011. 
Focusing on the information communication technologies, the prevalence of phone lines stands out as the most generally influential, having a positive significant effect on all dependent variables except cars. Cell phone access does not significantly affect any of the dependent variables. The number of Internet users does not have a significant effect on any dependent variables except for the number of cars, where its effect is significant and positive. Taken together, the results provide no support for the hypothesis that the rise of information communication technologies will help conserve energy resources, and even suggest that information communication technologies may spur greater resource use.

To assess the robustness of these findings with regard to model and error specification, we took two approaches. First, we estimated less saturated versions of the models presented here, where some of the control variables that were not significantly influential were removed from the models so as to improve statistical power. Second, we estimated models that instead of correcting for autocorrelation, corrected for errors clustering by nation. In general, these approaches produced models where the direction of effect was the same for the three key information communication technology variables as in the models presented here, but the significance level did differ in some cases. In some model/error specifications the effect of cell phones was statistically significant and positive. In contrast, in some model specifications the effect of Internet users was significant and negative. This latter finding does provide some support for the claim that information communication technologies can have some beneficial effects on resource conservation, but since it is coupled with the opposite finding that cell phones spur resource use, the overall picture remains the same as that suggested by the main models we present here: there is not substantial support for the claim that information communication technologies are generally helping to conserve energy resources.

\section{Discussion and conclusion}

Growing concerns about climate change and other environmental problems have promoted efforts to develop ways to reduce fossil fuel use. A central approach for addressing this issue has been the development and application of new technologies that will allow for more efficient production in terms of the amount of energy use in relation to economic output. As Laitner and Ehrhardt-Martinez (2008, p. 53) have noted, "Energy efficiency is not about doing without energy resources, but about extracting greater value from our energy resources whether we put them to work as kilowatt-hours of electricity or gallons of gasoline." 
While there are multiple avenues for pursuing such goals, some economists and sociologists have suggested that a fundamental way to achieve this is through the dynamics of markets and technological change.

In regard to information communication technologies, their growth has generally been suggested to stimulate the expansion of energy efficiency, which can serve as a way to mitigate environmental concerns like climate change. These technologies have been considered important tools in developing more energy efficient production systems. Through both the application of new, less energyintensive production processes that include or are supported by information communication technologies, and changing the structure of the productive system, they can aid in decreasing general energy needs through mechanisms such as telecommuting or information communication systems. As a result, there is greater potential for the dematerialization of production.

We analyzed the effects of information communication technologies on energy production and consumption as well as on the number of cars used in nations, analyzing data for 1990 to 2012. We found that the prevalence of landline phones is positively associated with higher levels of energy and electricity production and consumption, and that the extent of Internet use is positively associated with the number of cars on the road. Also, the ubiquity of cell phones is not associated with the number of cars or with electricity or total energy production and consumption. These findings suggest that information communication technologies have not typically contributed to environmental reform and, in fact, may have exacerbated environmental problems. Thus, technological development in this sector has not necessarily advanced ecological modernization in the manner that the theory might expect. However, our results should be taken as preliminary, since some exploratory analyses we have done using different model specifications suggest the prevalence of Internet users may help to suppress some resource use, although these alternative models also suggest cell phone usage may serve to increase some types of resource use. Future research using more nuanced models and methods may be able to refine our findings and detect more subtle effects. Nonetheless, the overall picture presented by our results is that information communication technologies have not proven to be clearly beneficial for resource conservation.

Critical environmental sociologists have been skeptical of the ecological benefits of technological development in the modern socioeconomic context. Those drawing on the treadmill of production have theorized that modern capitalist production systems are geared towards growth, which usually occurs at the expense of the environment (Schnaiberg \& Gould, 1994). Other sociologists critical of the modernization perspective also propose that capital accumulation processes tend to advance profits, often at the expense of the environment (Foster, Clark, \& York, 2010). Our results lend support to these critical environmental 
sociological theories. That is, although information communication technologies have the potential to limit or reduce energy use, they are not likely to be applied in a manner that substantially reduces environmental impacts, but rather may be directed primarily at increasing profits.

Economists and some sociologists have argued that market mechanisms will bring about desired energy efficiency outcomes, as it is cost-effective to reduce energy use. Information communication technologies can transform production processes by lowering the energy requirements of production (producing more with less), or providing important information (e.g., on energy use), which can reduce waste. Structural changes to the economy associated with technological advances in this realm can affect general practices, such as reducing automobile commuting or providing information that can limit errors or unnecessary practices (e.g., limiting extra trips or redundant activities with easier and faster communication). Further, a more technology-intensive economy can be a more efficient economy, as information communication technologies require less energy and waste than traditional manufacturing systems.

Surely, in many specific instances these benefits may arise. However, our results do not suggest that this is generally occurring economy-wide in most nations. As environmental sociologists critical of traditional economic growth models have argued, in growth-oriented economies efficiencies may be outpaced by aggregate growth. Information communication technologies have the potential to increase energy efficiency and reduce environmental impacts. Nevertheless, this potential may not foster positive ecological benefits if the primary emphasis remains on capital growth rather than ecological efficiency.

\section{References}

Berkhout, F., \& Hertin, J. (2004). De-materialising and re-materialising: Digital technologies and the environment. Futures, 36, 903-920.

Dinda, S. (2004). Environmental Kuznets curve hypothesis: A survey. Ecological Economics, 49, 431-455.

Fisher, D. R., \& Freudenburg, W. R. (2001). Ecological modernization and its critics: Assessing the past and looking toward the future. Society and Natural Resources, 14, 701-709.

Foster, J. B., Clark, B., \& York, R. (2010). The ecological rift: Capitalism's war on the planet. New York: Monthly Review Press.

Foster, J. B. (1994). The Vulnerable Planet: A Short Economic History of the Environment. New York, NY: Monthly Review Press. 
Fuchs, C. (2008). The implications of new information and communication technologies for sustainability. Environment, Development and Sustainability, 10, 291-309.

Ghosh, S. (2002). Electricity consumption an economic growth in India. Energy Policy, 30, 125-129.

Goldemberg, J. (1998). Leapfrog energy technologies. Energy Policy, 26, 729-741.

Hilty, L. M., Arnfalk, O., Erdmann, L., Goodman, J., Lehmann, M., \& Wäger, P. P. A. (2006). The relevance of information and communication technologies for environmental sustainability - A prospective simulation study. Environmental Modeling \& Software, 21, 1618-1629.

Jorgenson, A. K., \& Clark, B. (2012). Are the economy and the environment decoupling? A comparative international study, 1960-2005. American Journal of Sociology, 118, 1-44.

Laitner, J. A. (2002). Information technology and US energy consumption: Energy hog, productivity tool, or both? Journal of Industrial Ecology, 6, 1324.

Laitner, J. A., \& Ehrhardt-Martinez, K. (2008). Information and communication technologies: The power of productivity (Part I). Environmental Quality Management, 18, 47-66.

Longo, S. B., Clausen, R., \& Clark, B. (2015). The tragedy of the commodity: Oceans fisheries and aquaculture. New Brunswick, NJ: Rutgers University Press.

Mathiesen, B. V., Lund H., \& Karlsson, K. (2009). 100\% Renewable energy systems, climate mitigation and economic growth. Applied Energy, 88, 488-501.

Mol, A. P. J. (2002). Ecological modernization and the global economy. Global Environmental Politics, 2, 92-115

Mol, A. P. J., \& Spaargaren, G. (2000). Ecological modernisation theory in debate: A review. Environmental Politics, 9, 17-49.

Moyer, J. D., \& Hughes, B. B. (2012). ICTs: Do they contribute to increased carbon emissions? Technological Forecasting and Social Change, 79, 919-931.

Plepys, A. (2002). The grey side of ICT. Environmental Impact Assessment Review, 22, 509-523. 
Romm, J., Rosenfeld, A., \& Herrmann, S. (1999). The Internet economy and global warming: A scenario of the impact of e-commerce on energy and the environment. Center for Energy and Climate Solutions, infohouse.p2ric.org/ ref/04/03784/0378401.pdf.

Romm, J. (2002). The Internet and the new energy economy. Resources, Conservation and Recycling, 3, 197-210.

Sandorsky, P. (2012). Information communication technology and electricity consumption in emerging economies. Energy Policy, 48, 130-136.

Schnaiberg, A. (1980). The environment: From surplus to scarcity. New York, NY: Oxford University Press.

Schnaiberg, A., \& Gould, K. A. (1994). Environment and society: The enduring conflict. New York, NY: St. Martin's Press.

Simon, J. L. (1981). The ultimate resource. Princeton, NJ: Princeton University Press.

Van Heddeghem, W., Lambert, S., Lannoo, B., Colle, D., Pickavet, M., \& Demeester, P. (2014). Trends in worldwide ICT electricity consumption from 2007 to 2012. Computer Communications, 50, 64-76.

Walker, W. (1985). Information technology and the use of energy. Energy Policy, $13,458-476$.

Walker, W. (1986). Information technology and energy supply. Energy Policy, $14,466-488$.

York, R. (2006). Ecological paradoxes: William Stanley Jevons and the paperless office. Human Ecology Review, 13(2), 143-147.

York, R., \& Clark, B. (2010). Critical materialism: Science, technology, and environmental sustainability. Sociological Inquiry, 80(3), 475-499.

York, R., Rosa, E. A., \& Dietz, T. (2003a). Footprints on the earth: The environmental consequences of modernity. American Sociological Review, 68, 279-300.

York, R., Rosa, E. A., \& Dietz, T. (2003b). STIRPAT, IPAT and ImPACT: Analytic tools for unpacking the driving forces of environmental impacts. Ecological Economics, 46, 351-365.

York, R., Rosa, E. A., \& Dietz, T. (2010). Ecological modernization theory: Theoretical and empirical challenges. In M. Redclift \& G Woodgate (Eds.), The International Handbook of Environmental Sociology, Second Edition (pp. 77-90). Cheltenham, UK: Edward Elgar. 
This text is taken from Human Ecology Review, Volume 22, Number 1, 2015, published 2015 by ANU Press, The Australian National University, Canberra, Australia. 